\title{
Giant paratesticular liposarcoma with lung metastases: a case report and review of the literature
}

\author{
Takuro Noguchi', Toshirou Fukushima ${ }^{1}$, Hiroaki Hara², Nodoka Sekiguchi ${ }^{1}$, Takashi Kobayashi', Takesumi Ozawa ${ }^{1}$,
} Daisuke Gomi ${ }^{1}$ and Tomonobu Koizumi ${ }^{*}$

\begin{abstract}
Background: Due to its rarity, little is known about the clinical presentations and responses to systemic chemotherapies in advanced and/or metastatic cases of paratesticular liposarcoma.

Case presentation: Here, we report the case of a 75-year-old Japanese man with giant paratesticular liposarcoma. Imaging studies revealed a $26 \mathrm{~cm}$ tumor in his right scrotum and lung metastases at presentation. He underwent radical orchiectomy followed by systemic chemotherapies. Pathological findings of the resected primary tumor confirmed a dedifferentiated liposarcoma. He then started chemotherapy treatment with gemcitabine plus docetaxel. His disease status was stable for 1 year. Eribulin was used for second-line chemotherapy. He had a relapse at 5 months after eliburin and died at 22 months after diagnosis.

Conclusion: Early diagnosis and curative radical surgery are important for treatment of paratesticular liposarcoma. However, a giant paratesticular liposarcoma could cause metastases, and systemic chemotherapy may be helpful for prolonging survival in patients with metastatic paratesticular liposarcoma.
\end{abstract}

Keywords: Paratesticular liposarcoma, Chemotherapy, Pulmonary metastasis

\section{Background}

Urological sarcomas are rare tumors accounting for $2.7 \%$ of all soft tissue sarcomas across organs in adult patients [1]. Paratesticular liposarcoma (PTL) is relatively common among the urological sarcomas in the literature [1-5], however, PTL is an extremely rare clinical entity. Based on previous case studies and recent reviews [3-9], approximately more than 200 cases of PTL have been reported to date. PTLs mostly present as a painless, slow-growing inguinal or inguinoscrotal mass $[2,3,8,9]$. In general, surgical approaches, including radical orchiectomy with wide local excision and

\footnotetext{
* Correspondence: tomonobu@shinshu-u.ac.jp

'Department of Comprehensive Cancer Therapy, Shinshu University School of Medicine, 3-1-1 Asahi, Matsumoto 390-8621, Japan

Full list of author information is available at the end of the article
}

high ligation of the spermatic cord, should be performed in cases of suspected PTL [2-5]. However, 1-5\% of patients with paratesticular sarcoma, including PTL, present with metastatic disease [2-5]. Their extremely low incidence hampers our understanding of metastatic PTLs in terms of clinical presentations, effective chemotherapeutic regimens, and prognosis. We encountered a case of a patient with giant PTL with lung metastases at the initial diagnosis. Here, we report its clinical course because the present case had a huge paratesticular liposarcoma, and relatively prolonged control was obtained by serial chemotherapies. We also present a review of the disease and discuss the role of chemotherapies.

(c) The Author(s). 2020 Open Access This article is licensed under a Creative Commons Attribution 4.0 International License, which permits use, sharing, adaptation, distribution and reproduction in any medium or format, as long as you give appropriate credit to the original author(s) and the source, provide a link to the Creative Commons licence, and indicate if changes were made. The images or other third party material in this article are included in the article's Creative Commons licence, unless indicated otherwise in a credit line to the material. If material is not included in the article's Creative Commons licence and your intended use is not permitted by statutory regulation or exceeds the permitted use, you will need to obtain permission directly from the copyright holder. To view a copy of this licence, visit http://creativecommons.org/licenses/by/4.0/ The Creative Commons Public Domain Dedication waiver (http://creativecommons.org/publicdomain/zero/1.0/) applies to the data made available in this article, unless otherwise stated in a credit line to the data. 
Table 1 Blood chemistroies on admission

\begin{tabular}{|c|c|c|c|c|c|}
\hline $\mathrm{TP}$ & $7.4 \mathrm{~g} / \mathrm{dl}$ & $\mathrm{Na}$ & $137 \mathrm{mmol} / \mathrm{l}$ & CEA & $1.4 \mathrm{ng} / \mathrm{ml}$ \\
\hline Alb & $4.4 \mathrm{~g} / \mathrm{dl}$ & $\mathrm{Cl}$ & $102 \mathrm{mmol} / \mathrm{l}$ & $\mathrm{KL}-6$ & $215 \mathrm{U} / \mathrm{ml}$ \\
\hline UN & $7.8 \mathrm{mg} / \mathrm{dl}$ & $\mathrm{K}$ & $4.2 \mathrm{mmol} / \mathrm{l}$ & & \\
\hline Cre & $0.74 \mathrm{mg} / \mathrm{dl}$ & $\mathrm{Ca}$ & $9.0 \mathrm{mg} / \mathrm{dl}$ & & \\
\hline AST & $19 \mathrm{IU} / \mathrm{L}$ & Glu & $111 \mathrm{mg} / \mathrm{dl}$ & & \\
\hline ALT & $13 \mathrm{IU} / \mathrm{L}$ & & & & \\
\hline $\vee \mathrm{GTP}$ & $27 \mathrm{U} / \mathrm{L}$ & WBC & $5.50 \times 10^{3} / \mu l$ & & \\
\hline T-bil & $0.32 \mathrm{mg} / \mathrm{dl}$ & $\mathrm{RBC}$ & $4.32 \times 10^{6} / \mu l$ & & \\
\hline ALP & $210 \mathrm{U} / \mathrm{L}$ & $\mathrm{Hb}$ & $11.7 \mathrm{~g} / \mathrm{dl}$ & & \\
\hline $\mathrm{LDH}$ & $158 \mathrm{U} / \mathrm{L}$ & Hct & $33.2 \%$ & & \\
\hline & & Plt & $26.4 \times 10^{4} \mu \mathrm{l}$ & & \\
\hline
\end{tabular}

\section{Case presentation}

A 75-year-old Japanese man complained of a swollen right scrotum, which had grown slowly for 1 year. A huge elastic hard mass was palpable in his right scrotum. The surface of the skin showed no redness, rash, ulcers, or other skin abnormalities. He had neither pain nor obstruction of urination. He had worked as a farmer for a long time. He had a smoking history (20 pack-year) but did not consume alcohol. There was no history of disease or surgery. There was no specific family history, including of cancer. Physical and neurological examinations were normal, except for a $26 \mathrm{~cm}$ tumor in his right scrotum and right inguinal lymphadenopathy $(3 \mathrm{~cm})$. His blood pressure was $146 / 80$, heart rate 86 , and temperature 36.8 degrees. Laboratory findings are shown in Table 1; there were no abnormal findings. The findings by computed tomography (CT) were shown in Fig. 1a. In addition, multiple lung nodules were detected on chest CT (Fig. 2). Our patient underwent radical orchiectomy and lymph node dissection. Histological analysis revealed the proliferation of spindle and pleomorphic cells containing bizarre hyperchromatic nuclear cells with both poorly and well-differentiated areas. On immunohistochemistry, tumor cells were negative for cytokeratin AE1/AE3, desmin, S-100, STAT6, BCL-2, and MIC2, but positive for smooth muscle actin, CDK4, and MDM2 (Fig. 3). These findings led to a pathological diagnosis of dedifferentiated PTL. Histological examination showed no microscopic invasion to the testis. Based on the soft tissue sarcoma classification, the disease was T2bN1M1 (IV) stage. At 2 months after surgery, the lung nodules showed rapid progression $(+40 \%$ for 2 months) (Fig. 2). First-line treatment was then started with gemcitabine $\left(1000 \mathrm{mg} / \mathrm{m}^{2}\right.$ day 1$)$ plus docetaxel $(30 \mathrm{mg} /$ $\mathrm{m}^{2}$, day 1 ) chemotherapy every 2 weeks. The metastasis in his left lung was set as a target lesion by chest radiography.

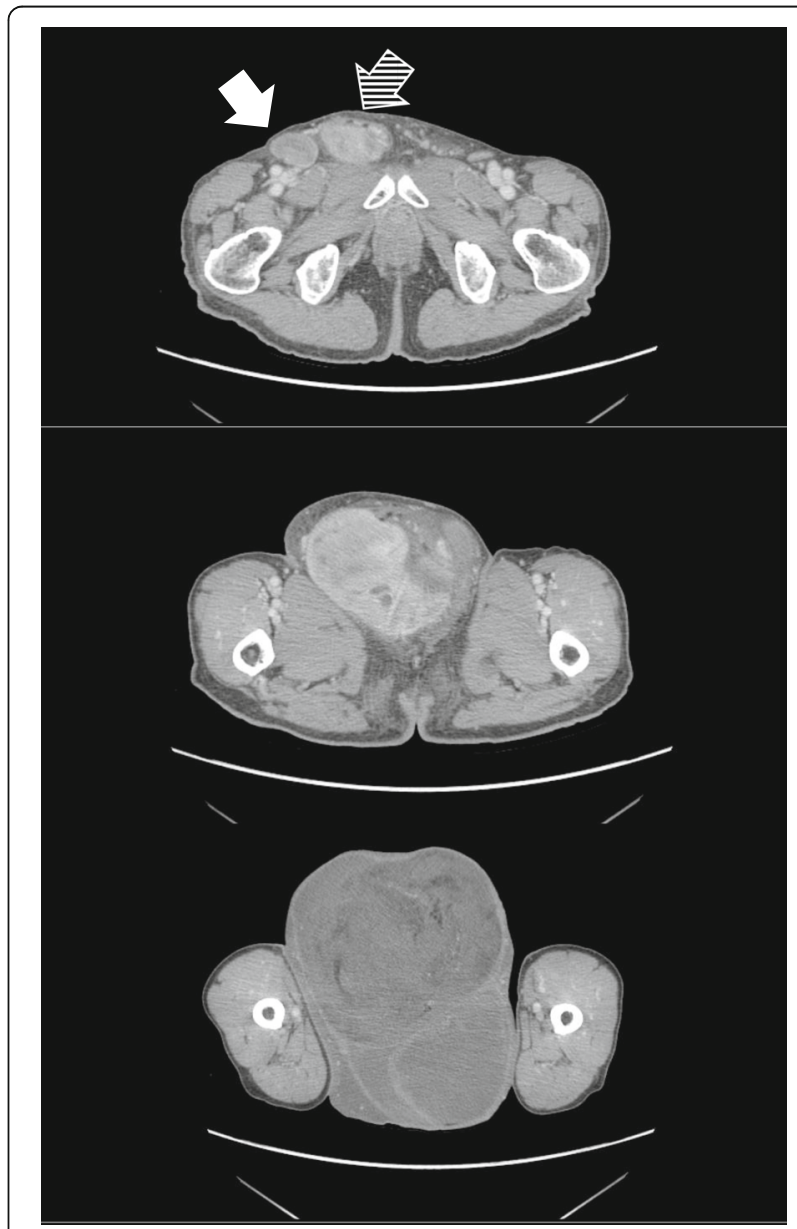

Fig. 1 Enhanced computed tomography scan revealed a solid tumor in the right scrotum. The tumor consisted of the enhanced lesion (middle) and one with adipose density (bottom). Right inguinal lymphadenopathy (top, white arrow) and the extended tumor in the inguinal canal (top, striped arrow) were observed 

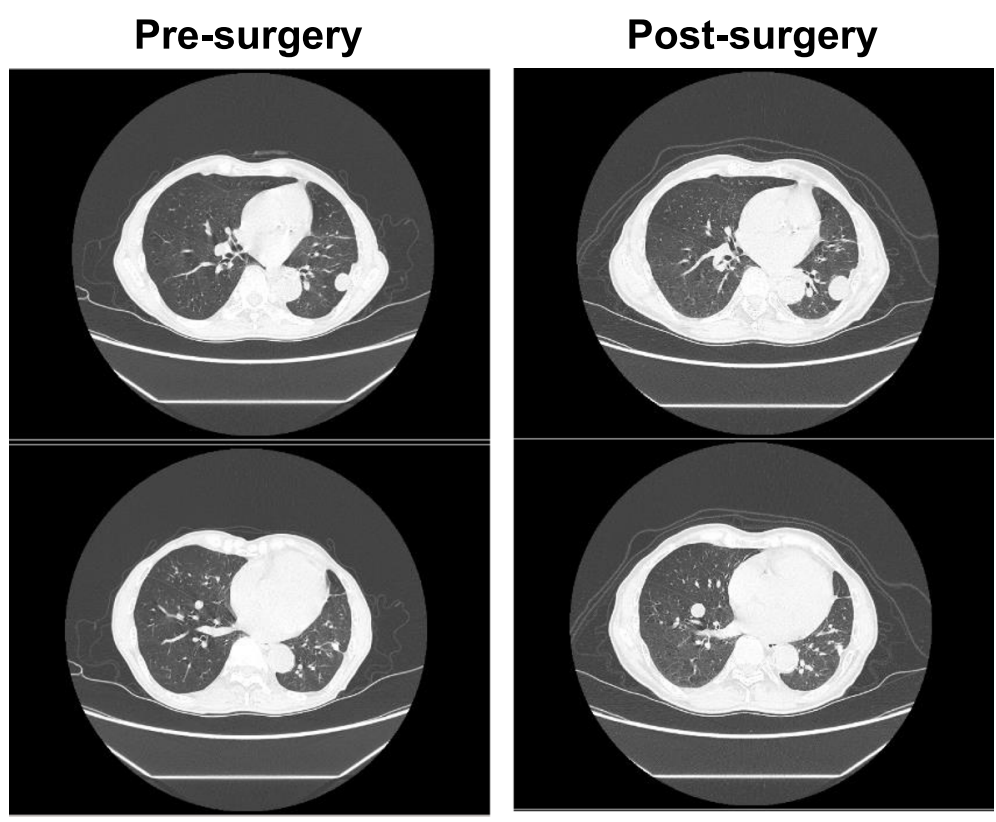

Fig. 2 Multiple lung nodules were found at presentation (left). At 2 months after orchiectomy, the nodules were enlarged in size (right)

The time course of the imaging studies is shown in Fig. 4. The disease was well controlled by gemcitabine plus docetaxel chemotherapy for 1 year without any adverse events until its progression. We subsequently performed secondline eribulin $\left(1.4 \mathrm{mg} / \mathrm{m}^{2}\right.$, day 1,8 , every 3 weeks) chemotherapy. Despite the progression of the lung metastases, his symptoms remained stable. However, at 4.5 months after second-line chemotherapy, chest radiography showed progression of metastatic nodules and the presence of pleural effusion. In all, he underwent chemotherapy for 18 months and died at 22 months after diagnosis. An autopsy was not performed.

\section{Discussion}

We described a case of a patient with giant paratesticular liposarcoma initially presenting with pulmonary metastases, and the treatment outcome along with serial chemotherapies. Such a huge tumor is extremely rare, and little information about the usefulness of chemotherapy exists about paratesticular liposarcoma.

Malignant liposarcoma is classified into the following subtypes: dedifferentiated, myxoid/round cell, and pleomorphic liposarcoma [10]. Like other liposarcomas, the prognosis of PTL depends on its histology. The welldifferentiated (intermediate of lipomatous tumors) and

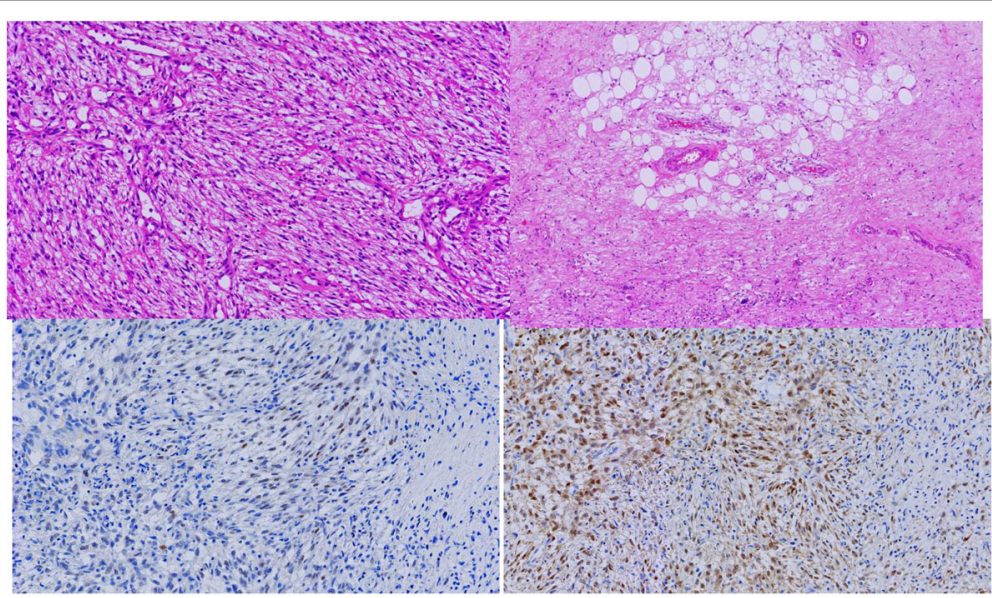

Fig. 3 Histological findings revealed the proliferation of spindle and pleomorphic cells containing bizarre hyperchromatic nuclear cells with both poorly (left upper) and well-differentiated areas (right upper). They were positive for CDK4 (left lower) and MDM2 (right lower). Magnification, $\times 20$ 


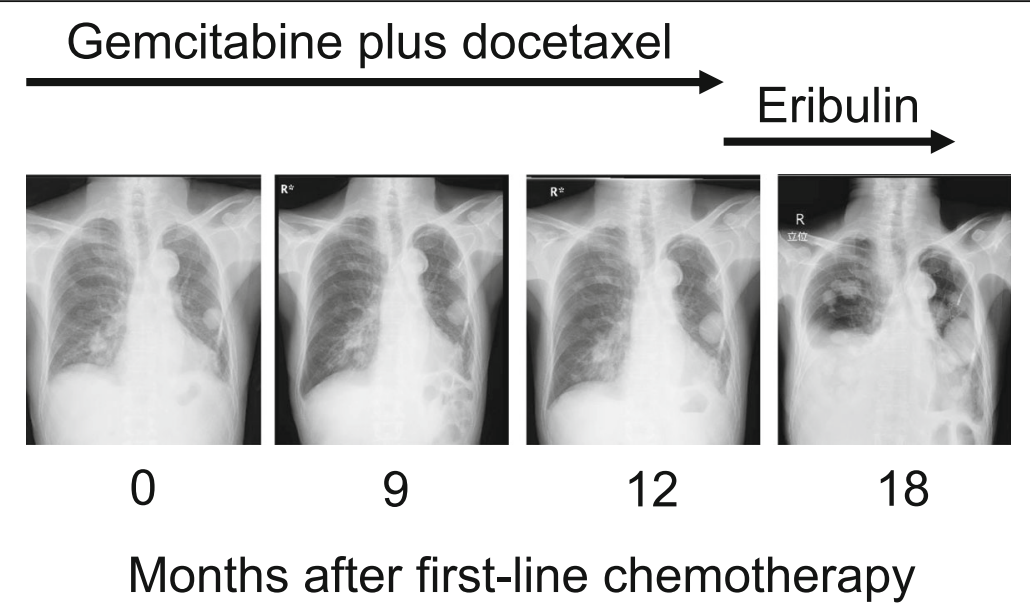

Fig. 4 Serial chest radiographic findings after chemotherapy

myxoid/round cell types have a better prognosis, but they tend to have high incidence rates of local recurrence $[2,3,11]$. PTL typically affects adults, with the most common age at presentation being 50-60 years [5]. Diagnosis of PTL is challenging in some cases because their clinical manifestations mimic groin hernia, hydrocele, or other benign lesions $[12,13]$. Testicular tumors more than $10 \mathrm{~cm}$ in diameter are called "giant" [13]. Several giant PTLs have been reported $[8,12,14]$. However, the size of $26 \mathrm{~cm}$ in our case was relatively huge even among these previous reports.

There were no metastatic lesions in organs other than lungs, and systemic chemotherapy was initiated in the present case. The response rates of chemotherapies, such as doxorubicin, ifosfamide alone, or in combination, are generally low and the response rates to these agents also vary according to histological types in soft tissue sarcomas [15]. Jones et al. examined the differential sensitivity of liposarcoma subtypes to chemotherapy [16]. Myxoid liposarcoma was relatively chemo-sensitive compared to dedifferentiated or well-differentiated liposarcoma. Indeed, the response rate of dedifferentiated liposarcoma to first-line chemotherapy was only $25 \%$ (doxorubicin, $8 \%$; doxorubicin plus ifosfamide, $17 \%$ ). In our case, because of his advanced age and performance status, our patient was considered contraindicated for anthracycline-based chemotherapies, leading to the choice of gemcitabine plus docetaxel. In real-world data based on the Surveillance, Epidemiology and End Results (SEER) in the United States [17] and the medical record review in Europe [18], gemcitabine plus docetaxel chemotherapy was most commonly used in older patients with soft tissue sarcoma. In a phase 2, open-label study, this drug combination showed antitumor activities (response rate $16 \%$ ) for metastatic soft tissue sarcomas, including liposarcoma [19]. Although complete response to gemcitabine plus docetaxel in a patient with retroperitoneal liposarcoma was reported [20], information about chemotherapeutic responses in PTL is limited. First-line chemotherapy using the combination of gemcitabine plus docetaxel continued for 1 year until disease progression in the present case. As the lung metastases progressed rapidly without systemic treatment after surgery for only 2 months, the chemotherapy used here was conceivably efficacious.

Eribulin, a microtubule growth inhibitor, was highly efficacious in patients with advanced liposarcoma [21]. However, second-line chemotherapy using eribulin was unlikely to be effective in the present case, because of early progression of pulmonary metastatic lesions.

In the SEER data, median survival time in registered patients with advanced liposarcomas was 21.1 months [17]. The survival time of 22 months in our case initially presenting giant primary tumor and lung metastasis was comparable to other reports. Therefore, although evidence on effective chemotherapies for PTL is limited, we believe that systemic chemotherapy could have contributed to the survival in the present case. Dedifferentiated liposarcomas have genetic abnormalities with high-level amplification of chromosome 12q14-15, which includes the MDM2 and CDK4 cell cycle oncogenes [11,22]. Based on the phase 2 trial of the CDK4 inhibitor, palbociclib [22], there was one complete response among 59 evaluable patients and the median progression free survival (PFS) was 17.9 weeks (two-sided 95\% CI: 11.9-24.0 weeks). Further investigations of the molecular characteristics would be useful for the development of novel therapeutic targeted agents or to understand the etiology and risk factors in patients with PTL.

\section{Conclusion}

We described a case of giant paratesticular liposarcoma initially presenting with pulmonary metastases, along with the treatment outcome. Although systemic chemotherapy may be helpful for prolonging survival, further studies regarding therapeutic strategies for inoperable and metastatic paratesticular liposarcomas are warranted. 


\section{Acknowledgements}

None.

\section{Authors' contributions}

$\mathrm{HH}$ contributed to surgery and TN, TF, NS, TK, TO, DG, and TK contributed to medical treatments in the present case. $\mathrm{TN}, \mathrm{HH}$, and TK wrote the manuscript. All authors read and approved the final manuscript.

\section{Funding}

None.

\section{Availability of data and materials}

Not applicable.

Ethics approval and consent to participate

Ethical approval was not relevant or applicable to this case report.

\section{Consent for publication}

Written informed consent was obtained for the treatment from the patient In addition, written informed consent was obtained from the patient's next of kin for publication of this case report and any accompanying images. A copy of the written consent is available for review by the Editor-in-Chief of this journal.

\section{Competing interests}

The authors declare that they have no competing interests.

\section{Author details}

'Department of Comprehensive Cancer Therapy, Shinshu University School of Medicine, 3-1-1 Asahi, Matsumoto 390-8621, Japan. ${ }^{2}$ Department of Urology, Shinshu University School of Medicine, 3-1-1 Asahi, Matsumoto 390-8621, Japan.

Received: 26 June 2019 Accepted: 28 May 2020

Published online: 02 July 2020

\section{References}

1. Russo P, Brady MS, Conlon K, Hajdu SI, Fair WR, Herr HW, et al. Adult urological sarcoma. J Urol. 1992;147:1032-6.

2. Rodríguez D, Barrisford GW, Sanchez A, Preston MA, Kreydin El, Olumi AF. Primary spermatic cord tumors: disease characteristics, prognostic factors, and treatment outcomes. Urol Oncol. 2014;32:52.e19-25.

3. Goldberg H, Wong L-M, Dickson B, Catton C, Yap SA, Alkasab T, et al. Longterm oncological outcomes of patients with paratesticular sarcoma. BJU Int. 2019:25:480

4. Wang X, Tu X, Tan P, Zhan W, Nie P, Wei B, et al. Adult genitourinary sarcoma: clinical characteristics and survival in a series of patients treated at a high-volume institution. Int J Urol. 2017;24:425-31.

5. Fitzgerald S, Maclennan GT. Paratesticular liposarcoma. J Urol. 2009:181:331-2.

6. Chiodini S, Luciani LG, Cai T, Molinari A, Morelli L, Cantaloni C, Barbareschi $\mathrm{M}$, et al. Unusual case of locally advanced and metastatic paratesticular liposarcoma: a case report and review of the literature. Arch Ital Urol Androl. 2015;87:87-9.

7. Schwartz SL, Swierzewski SJ 3rd, Sondak VK, Grossman HB. Liposarcoma of the spermatic cord: report of 6 cases and review of the literature. J Urol. 1995:153:154-7.

8. Montgomery E, Fisher C. Paratesticular liposarcoma: a clinicopathologic study. Am J Surg Pathol. 2003:27:40-7.

9. Li Z, Zhou L, Zhao L, Chen P, Liu Y, Ding Y, et al. Giant paratesticula liposarcoma: a case report and review of the literature. Mol Clin Oncol. 2018:8:617-22.

10. Fletcher CDM, Bridge JA, Hogendoorn PCW, Mertens F. WHO classification of tumours of soft tissue and bone. Geneva: World Health Organization; 2013.

11. Thway K, Jones RL, Noujaim J, Zaidi S, Miah AB, Fisher C. Dedifferentiated liposarcoma: updates on morphology, genetics, and therapeutic strategies. Adv Anat Pathol. 2016:23:30-40.

12. Cariati A, Brignole E, Tonelli E, Filippi M. Giant paratesticular undifferentiated liposarcoma that developed in a long-standing inguinal hernia. Eur J Surg. 2002;168:511-2.
13. Thomas KL, Gonzalez RJ, Henderson-Jackson E, Caracciolo JT. Paratesticula liposarcoma masquerading as an inguinal hernia. Urology. 2018;113:e5-6.

14. Kin T, Kitsukawa S, Shishido T, Maeda Y, Izutani T, Yonese J, et al. Two cases of giant testicular tumor with widespread extension to the spermatic cord: usefulness of upfront chemotherapy. Hinyokika Kiyo. 1999;45:191-4. [in Japanese].

15. Schöffski P, Cornillie J, Wozniak A, Li H, Hompes D. Soft tissue sarcoma: an update on systemic treatment options for patients with advanced disease. Oncol Res Treat. 2014:37:355-62.

16. Jones RL, Fisher C, Al-Muderis O, Judson IR. Differential sensitivity of liposarcoma subtypes to chemotherapy. Eur J Cancer. 2005;41:2853-60.

17. Parikh RC, Lorenzo M, Hess LM, Candrilli SD, Nicol S, Kaye JA. Treatment patterns and survival among older adults in the United States with advanced soft-tissue sarcomas. Clin Sarcoma Res. 2018;3:8.

18. Nagar SP, Mytelka DS, Candrilli SD, D'yachkova Y, Lorenzo M, Kasper B. Treatment patterns and survival among adult patients with advanced soft tissue sarcoma: a retrospective medical record review in the United Kingdom, Spain, Germany, and France. Sarcoma. 2018;2018:5467057.

19. Maki RG, Wathen JK, Patel SR, Priebat DA, Okuno SH, Samuels B, et al. Randomized phase II study of gemcitabine and docetaxel compared with gemcitabine alone in patients with metastatic soft tissue sarcomas: results of sarcoma alliance for research through collaboration study 002 [corrected]. J Clin Oncol. 2007;25:2755-63.

20. Da Silva FR, Lima AVJ, Albuquerque EWRP, Moreira-Silva CA, De Oliveira NMF, Ohana JAL, et al. Complete remission of recurrent retroperitoneal liposarcoma after the administration of gemcitabine and docetaxel as firstline adjuvant chemotherapy: a case report. Case Rep Oncol. 2018;11:341-6.

21. Schöffski P, Chawla S, Maki RG, Italiano A, Gelderblom H, Choy E, et al. Eribulin versus dacarbazine in previously treated patients with advanced liposarcoma or leiomyosarcoma: a randomised, open-label, multicentre, phase 3 trial. Lancet. 2016:387:1629-37.

22. Dickson MA, Schwartz GK, Keohan ML, D'Angelo SP, Gounder MM, Chi P, et al. Progression-free survival among patients with well-differentiated or dedifferentiated liposarcoma treated with cdk4 inhibitor palbociclib: a phase 2 clinical trial. JAMA Oncol. 2016;2:937-40.

\section{Publisher's Note}

Springer Nature remains neutral with regard to jurisdictional claims in published maps and institutional affiliations.

Ready to submit your research? Choose BMC and benefit from:

- fast, convenient online submission

- thorough peer review by experienced researchers in your field

- rapid publication on acceptance

- support for research data, including large and complex data types

- gold Open Access which fosters wider collaboration and increased citations

- maximum visibility for your research: over $100 \mathrm{M}$ website views per year

At BMC, research is always in progress.

Learn more biomedcentral.com/submissions 